\title{
Wiek walów morenowych we wschodniej części przedpola lodowca Fláa (SE Islandia) w oparciu o wyniki datowania lichenometrycznego
}

\author{
The age of the moraine ridges in the eastern part of Fláajökull foreland (SE Iceland) based \\ on the results of lichenometric dating
}

\author{
Katarzyna Luszczak $^{1,2}$, Aneta Modzelewska ${ }^{3}$, Daria Sawicka ${ }^{3}$, Dominika Niezabitowska ${ }^{1}$, \\ Maciej Dąbski ${ }^{3}$ \\ ${ }^{1}$ Kolegium Międzywydziałowych Indywidualnych Studiów Matematyczno-Przyrodniczych, Uniwersytet Warszawski, Warszawa \\ ${ }^{2}$ School of Geographical and Earth Science, University of Glasgow, Great Britain, k.luszczak.1@research.gla.ac.uk \\ ${ }^{3}$ Wydziat Geografii i Studiów Regionalnych, Uniwersytet Warszawski, Warszawa
}

\begin{abstract}
Zarys treści: Wyniki datowania lichenometrycznego trzech wałów morenowych położonych we wschodniej części przedpola lodowca Fláa zostały opracowane w oparciu o pomiary plech Rhizocarpon przy zastosowaniu: i) analizy gradientu rozkładu częstości populacji (GSF), ii) metody największej plechy (LL), iii) metody średniej z pięciu największych plech oraz (5LL) iv) metody pojedynczej przewidywanej plechy (1-IN-1000). Stwierdzono, że maksymalny zasięg lodowca Fláa w małej epoce lodowej przypada na przełom XIX i XX w. Ponadto wykazano niejednorodne tempo recesji czoła lodowca w obrębie jednego lobu oraz wyraźny wpływ warunków mikrośrodowiskowych na liczebność porostów i tempo ich wzrostu.
\end{abstract}

Słowa kluczowe: datowanie lichenometryczne, moreny czołowe, mała epoka lodowa, lodowiec Fláa, Islandia

\begin{abstract}
The results of lichenometric dating of Fláajökull moraine ridges located in the eastern part of its marginal zone have been carried out on the base of measurements of the Rhizocarpon thalli and using analyses of: i) the size-frequency distribution gradient (GSF), ii) the largest lichen (LL), iii) the five largest lichens (5LL), and iv) "1-IN-1000" method. It was found that the maximum extent of the glacier in the Little Ice Age occurred at the turn of $19^{\text {th }}$ and $20^{\text {th }}$ centuries. Moreover, the results indicate that the glacier recession rate was not consistent in all parts of the snout and that micro-environmental conditions significantly influence lichen populations and the lichen growth rate.
\end{abstract}

Key words: lichenometric dating, terminal moraines, Little Ice Age, Fláajökull, Iceland

\begin{abstract}
Wstęp
Datowania stref marginalnych jęzorów lodowcowych wypływających na $\mathrm{S}$ z czaszy lodowej Vatna były prowadzone zarówno metodami lichenometrycznymi (Bradwell 2001, Dąbski 2002, 2007, McKinzey i in. 2004), jak i za pomocą młotka Schmidta (Evans i in. 1999, Dąbski 2012), tefrostratygrafii (Bradwell 2006) oraz analizy chropowatości (Dąbski 2012). Wyniki poprzednich badań wskazują na największy zasięg lodowca Fláa w XIX w. AD 1870-1894 (Evans i in. 1999, Dąbski 2002, 2007) lub AD 1807-1831 (Chenet i in. 2010). W przedstawionych
\end{abstract}

badaniach wybrano metody lichenometryczne ze względu na ich niskie koszty i wymagania sprzętowe, a szczególnie $\mathrm{w}$ związku z wcześniejszymi opracowaniami wieku form na przedpolu lodowca Fláa. Do głównych celów badań należały weryfikacja wyników analizy lichenometrycznej wykonanej uprzednio w części południowej wałów morenowych lodowca Fláa (por. Dąbski 2007) oraz ocena zmienności czasu depozycji moren w poszczególnych częściach przedpola tego lodowca.

Uniwersalną metodykę datowania wieku moren jęzorów lodowcowych wschodniej części lodowca Vatna $\mathrm{z}$ zastosowaniem lichenometrii opracował Bradwell 
(2004). Tempo kurczenia się czaszy lodowca Vatna było badane na przykładzie kilku jej jęzorów wypustowych, m.in. Lambatunganajökull (Bradwell 2001, 2006) i Hoffelsjökull (Bradwell 2001), których największy zasięg oceniany jest na koniec XVIII w.

Metoda gradientu rozkładu częstości została uznana za dającą bardziej reprezentatywne wyniki w porównaniu $\mathrm{z}$ metodą największej plechy lub średniej pięciu największych plech (Bradwell 2006). Na procedurach opracowanych przez Bradwella bazowano w późniejszych badaniach (McKinzey i in. 2004, Dąbski 2007). Zastosowanie bardziej zaawansowanych analiz statystycznych, wykorzystywanych w przypadku metody GEV (ang. generalized extreme value, por. Naveau i in. 2005, 2007, Cooley $\mathrm{i}$ in. 2006), zostało uznane przez Bradwella (2009) za niezasadne. Tym samym autorzy opracowania użyli do datowania tradycyjnych metod lichenometrycznych, tj. metody gradientu rozkładu częstości, metodę największej plechy oraz średniej pięciu największych plech.

Wyniki badań glacjologicznych prowadzonych na lodowcu Fláa wykazały jego recesję o średnim tempie kilkadziesiąt metrów na rok (Sigurðsson 1998). Pomiary te były prowadzone wzdłuż 4 profili, z których pierwszy położony był na południowym lobie, zaś trzy kolejne na lobie wschodnim (Fláajökull Hólmsárgarður, Fláajökull austur 1, Fláajökull austur 2) (ryc. 1). Stwierdzono duże różnice w prędkości ruchu lodowca, także w obrębie tego samego, wschodniego lobu. Największą recesję lodowca zanotowano wzdłuż profilu Fláajökull austur 1, a najmniejszą wzdłuż profilu Fláajökull Hólmsárgarður. Szybkość recesji była zmienna w czasie, a nawet przerywana licznymi, krótkimi fazami transgresji (ryc. 2).

Na przedpolu lodowca Fláa dotychczasowe badania z wykorzystaniem metod lichenometrycznych obejmowały część południową przedpola wschodniego lobu tego lodowca. Daty uzyskane przy zastosowaniu metod największej plechy i średniej z pięciu największych plech zestawiono z danymi glacjologicznymi i kartograficznymi (Dąbski 2002). Stwierdzono, że datowanie $\mathrm{z}$ użyciem metod lichenometrycznych może zaniżać wiek wałów o blisko 15 lat przez przyjęcie zbyt szybkiego tempa rozwoju porostów. Wpływ na wyniki datowania może mieć także zmienność tempa przyrostu porostów (Dąbski 2002, 2005). Późniejsze badania na tym terenie zostały przeprowadzone w 2005 r., ponownie w części południowej wschodniego lobu lodowca (Dąbski 2007). Wiek moren obliczono metodą gradientu rozkładu częstości, w oparciu o krzywą referencyjną dla SE Islandii opracowaną przez Bradwella (2004). Wyniki zostały porównane z wcześniejszym datowaniem (Dąbski 2002). Stwierdzono, że największy zasięg lodowca Fláa występował u schyłku XIX w.

W artykule omówione zostaną wyniki datowania na podstawie pomiarów plech porostów wykonanych w sierpniu 2012 r. w części wschodniej przedpola wschodniego lobu jęzora lodowca Fláa, gdzie dotąd badania takie nie były prowadzone. Ich celem jest ustalenie wieku moren w części wschodniej przedpola lodowca z wyróżnie-

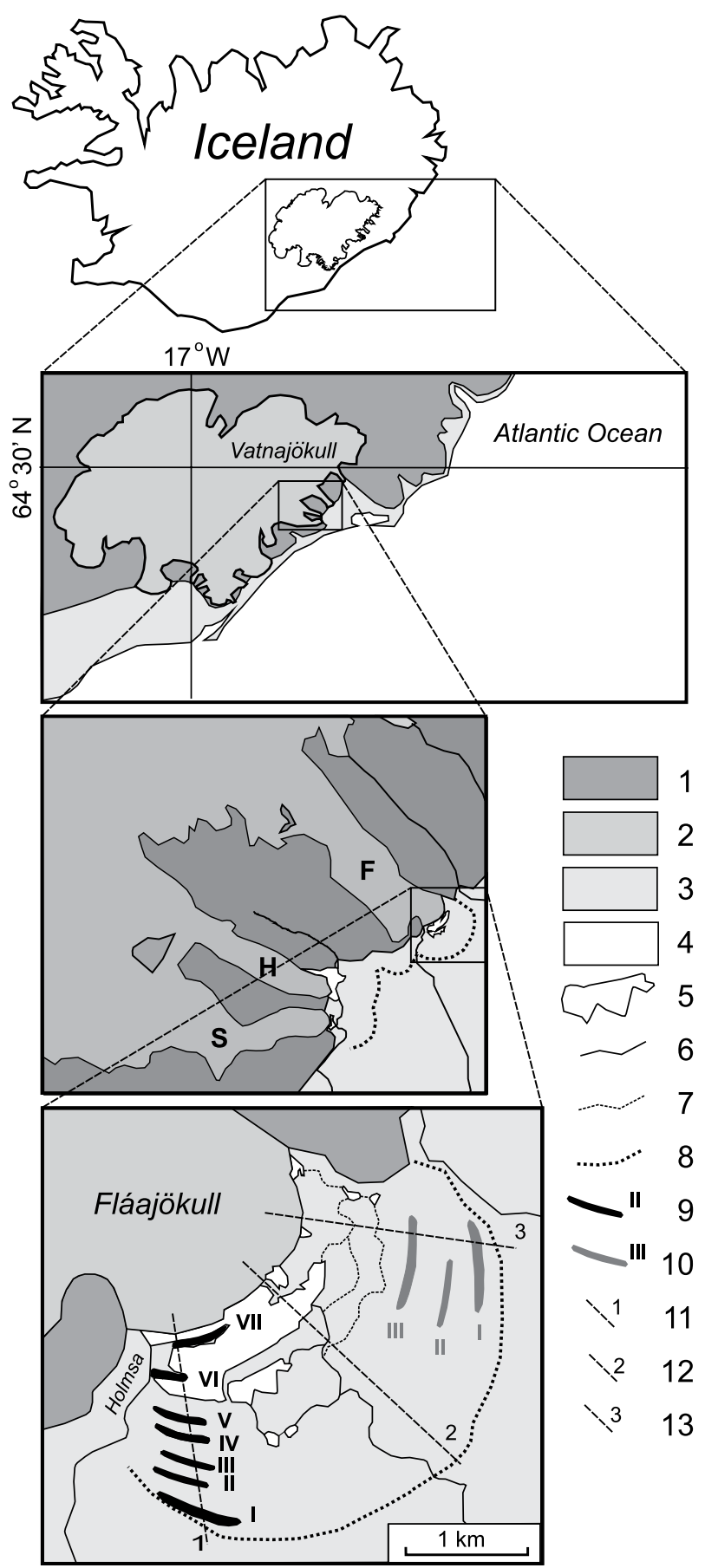

Ryc. 1. Przedpole lodowca Fláa z zaznaczonymi obszarami pomiarów lichenometrycznych wykonywanych przez autorów oraz przez Dąbskiego (2007)

F - lodowiec Fláa, H - lodowiec Heinabergs, S - lodowiec Skalafells; 1 wzniesienia, 2 - lodowiec, 3 - niziny, 4 - ocean, 5 - jezioro proglacjalne, 6 - rzeka, 7 - nieczynne koryto rzeczne, 8 - maksymalny zasięg wałów morenowych, 9 - wały morenowe badane przez Dąbskiego (2007), 10 wały morenowe badane przez autorów, 11 - profil glacjologiczny Fláajökull-Hólmsárgarđur, 12 - profil glacjologiczny Fláajökull austur 1, 13 - profil glacjologiczny Fláajökull austur 2

Fig. 1. The forefield of Fláajökull with areas of lichenometric measurements carried out by authors and by Dąbski (2007)

F - Fláajökull, H - Heinabergsjökull, S - Skalafellsjökull; 1 - highlands, 2 - glacier, 3 - lowlands, 4 - ocean, 5 - proglacial lake, 6 - river, 7 inactive river channel, 8 - maximum range of moraines, 9 - moraine ridges dated by Dąbski (2007), 10 - moraine ridges dated by authors, 11 - glaciological profile Fláajökull-Hólmsárgarđur, 12 - glaciological profile Fláajökull austur 1, 13 - glaciological profile Fláajökull austur 2 


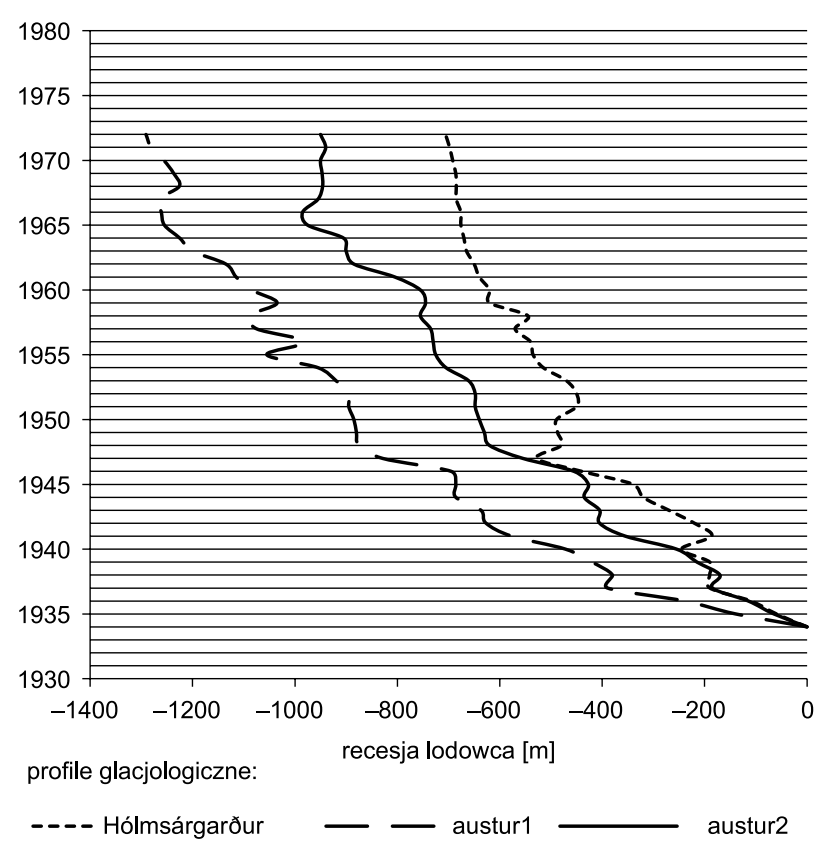

Ryc. 2. Tempo recesji lodowca Fláa od roku 1934 na podstawie badań glacjologicznych (Sigurðsson 1998)

Fig. 2. The recession rate of Fláajökull since 1934, derived from the glaciological data (Sigurðsson 1998)

niem tempa przyrostu porostów na różnych stronach otoczaków, tj. proksymalnej, dystalnej i wierzchowinowej. Ponadto w celu porównania wyników datowania dla jednego obiektu oraz ułatwienia korelacji z opublikowanymi danymi zestawiono różne metody lichenometryczne, a ich rezultaty porównano z wcześniejszymi, uzyskanymi dla południowej części przedpola badanego lobu jęzora lodowca Fláa.

\section{Obszar badań}

Badania wieku moren czołowych prowadzone były we wschodniej części przedpola lodowca Fláa (Fláajökull), na południowo-wschodniej Islandii (ryc. 1). Jest to lodowiec wypustowy z największej na wyspie czaszy lodowej Vatna (Vatnajökull). Czoło badanego lodowca podzielone jest na dwa loby, z których wschodni wykształcił wyraźne wały moren czołowych wraz z płatem moreny dennej, która jest miejscami zdrumlinizowana. Najstarszy z wałów moreny czołowej ma długość około $5,5 \mathrm{~km}$, a jego odległość od czoła lodowca to blisko 1,5 km. Wysokość strefy marginalnej lodowca Fláa wynosi od około 50 do 80 m n.p.m. i graniczy ona od wschodu z morenami lodowców Skálafells i Heinabergs. W trakcie małej epoki lodowej lodowce te łączyły się we wspólną stopę piedmontową (Dąbski i in. 1998).

\section{Metody badań}

W badaniach wykorzystano metodykę datowania lichenometrycznego stosowaną przez Dąbskiego (2007). Porosty pomierzono w sierpniu 2012 r., na grzbietach trzech wa- łów morenowych (I - wał najstarszy, III - wał najmłodszy), na głazach o zróżnicowanej litologii, głównie bazaltach, diabazach, dolerytach. Do pomiarów wybierano jedynie nie przylegające do siebie porosty o relatywnie okrągłych plechach, o średnicy powyżej $20 \mathrm{~mm}$, mierząc najdłuższą oś plechy (średnicę okręgu opisanego na plesze) z dokładnością do $1 \mathrm{~mm}$ (ryc. 3). Odnotowywano również ekspozycję powierzchni głazu porośniętej przez plechę w odniesieniu do położenia względem lodowca (P - proksymalna, czyli dolodowcowa, D - dystalna, czyli odlodowcowa, W - wierzchowinowa). Łącznie pomierzono 804 plechy porostu z rodzaju Rhizocarpon, około 270 na każdym z trzech wałów morenowych.

Wiek wałów morenowych obliczono na podstawie:

- metody analizy gradientu rozkładu częstości populacji plech (GSF - ang. the gradient of the size frequency distribution) (Bradwell 2004, McKinzey i in. 2004, Dąbski 2007),

- metody największej (najstarszej) plechy (LL - ang. the largest lichen) (Betschel 1950, Gordon, Sharp 1983),

- metody średniej z 5 największych plech (5LL - ang. the 5 largest lichens) (Thompson, Jones 1986, Evans $\mathrm{i}$ in. 1999, Dąbski 2002),

- metody pojedynczej przewidywanej plechy (1-IN1000) (Lock $i$ in. 1979).

Datowanie lichenometryczne oparte na metodzie GSF zapoczątkował Benedict (1967, 1985), a w badaniach islandzkich rozwinęli je Bradwell (2004) oraz McKinzey $\mathrm{i}$ in. (2004). Metoda ta polega na korelacji gradientu rozkładu częstości z wiekiem powierzchni skalnej. Pierwszy etap obliczeń sprowadza się do podziału rozmiarów plech na klasy o rozpiętości wielkości średnic w zakresie $3 \mathrm{~mm}$ i wykreślenia histogramów rozkładu częstości dla poszczególnych klas (ryc. 4). Wykresy częstości skon-

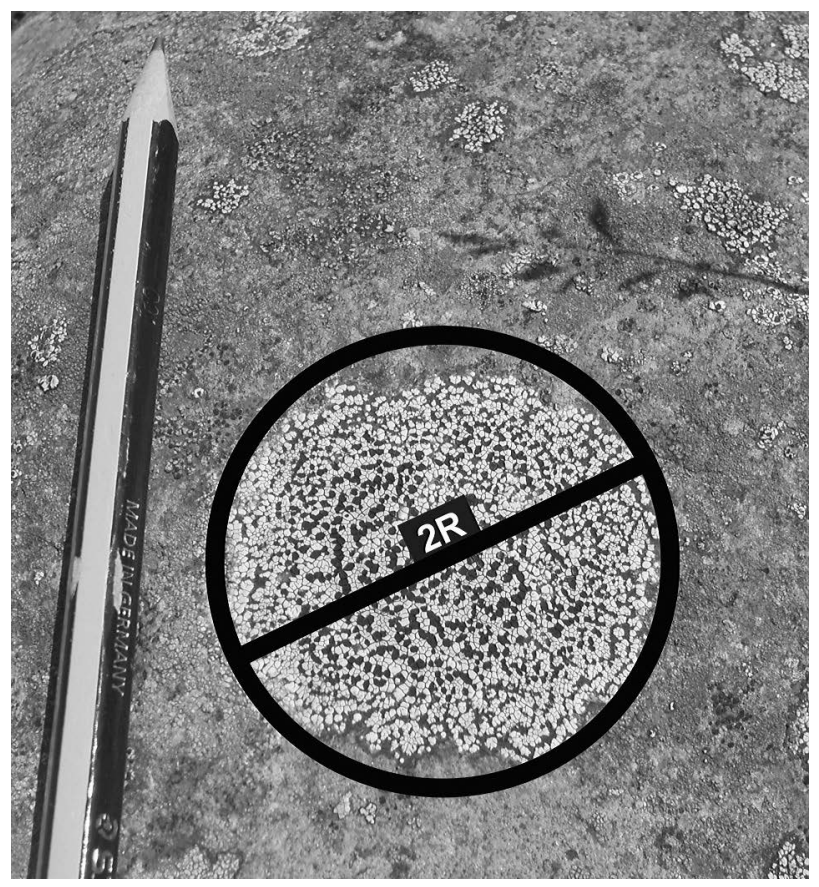

Ryc. 3. Sposób pomiaru średnicy plechy (2R)

Fig. 3. The method of measuring the thallus diameter (2R) 
A
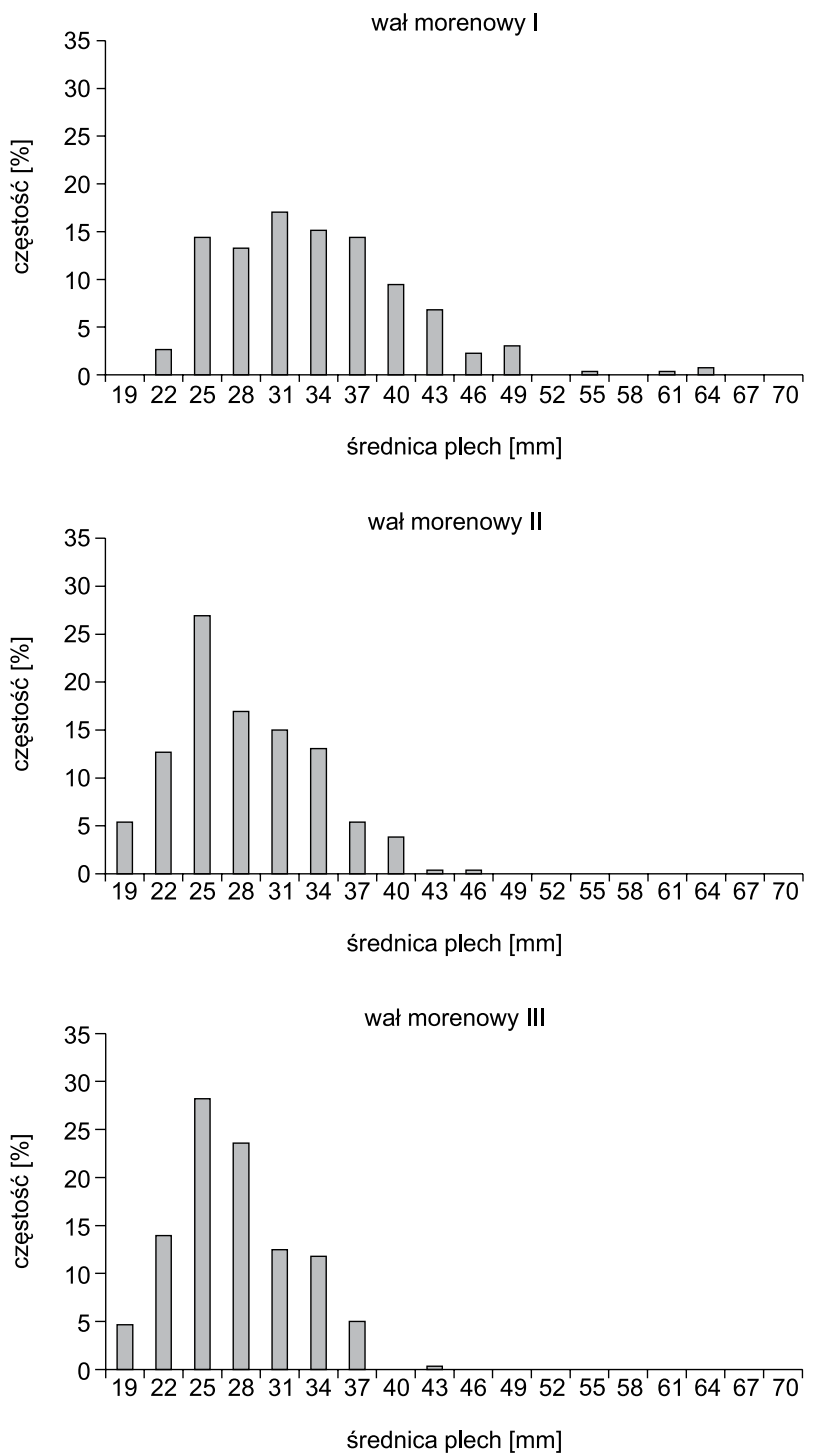

B

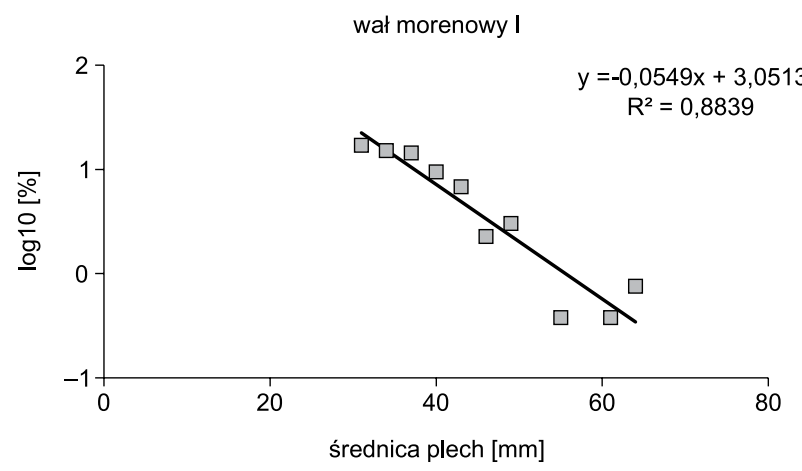

wał morenowy II

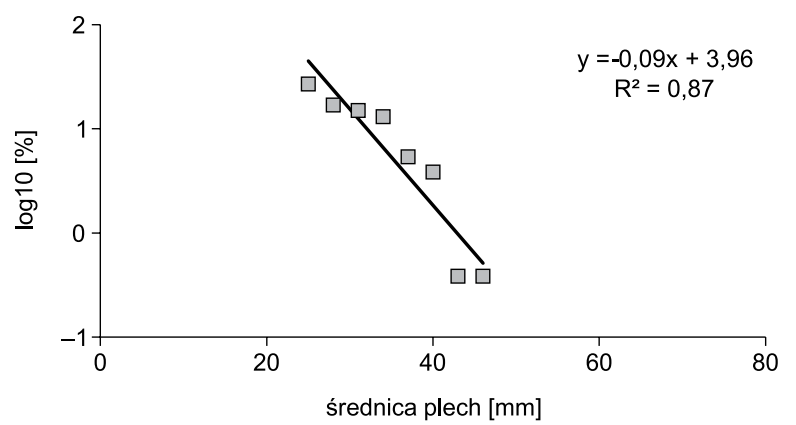

wał morenowy III

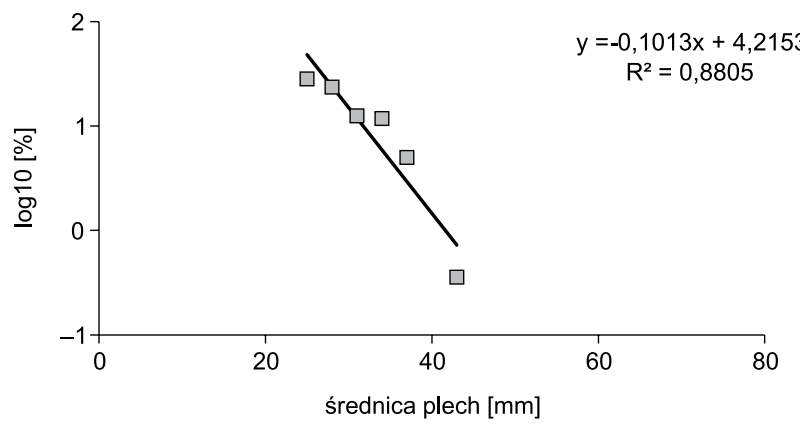

Ryc. 4. Rozkłady częstości występowania plech porostów (A) oraz krzywe regresji rozkładów częstości (B) dla poszczególnych wałów morenowych

Fig. 4. Size-frequency distributions of lichen thalli (A) and regression lines of size-frequency distributions (B) for each moraine ridge

struowano poprzez obliczenie logarytmu dziesiętnego z wartości częstości wyrażonej w procentach. Odrzucono klasy o wymiarach mniejszych niż klasa modalna. Krzywe regresji wykreślono za pomocą metody najmniejszych kwadratów. Efekt obliczeń stanowi funkcja liniowa o wzorze ogólnym: $y=m x+c$, gdzie $m$ oznacza gradient rozkładu częstości, a $c$ stanowi wyraz wolny prostej (ryc. 4). Otrzymane gradienty pomnożono przez współczynnik -1, aby zwiększyć czytelność wyników, a następnie zestawiono z empiryczną krzywą opracowaną przez Bradwella (2004) dla SE Islandii przedstawiającą zależność gradientu rozkładu częstości od wieku moren (ryc. 5).

Powyższy schemat zastosowano nie tylko dla populacji porastających poszczególne wały morenowe, ale również dla wydzielonych pod względem ekspozycji plech podgrup: proksymalnej, dystalnej i wierzchowinowej.

W przypadku pozostałych metod datowania lichenometrycznego do dalszych obliczeń przyjęto odpowiednio:

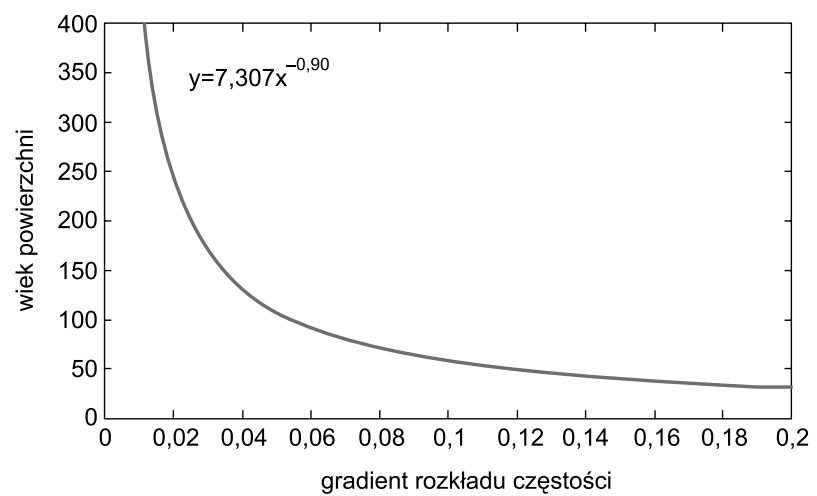

Ryc. 5. Krzywa lichenometryczna ilustrująca zależność wieku powierzchni skalnej od gradientu rozkładu częstości, opracowana dla SE Islandii przez Bradwella (2004)

Fig. 5. The lichenometric dating curve showing the dependence between the age of the rock surface and the gradient of the size-frequency distribution, elaborated by Bradwell (2004) 


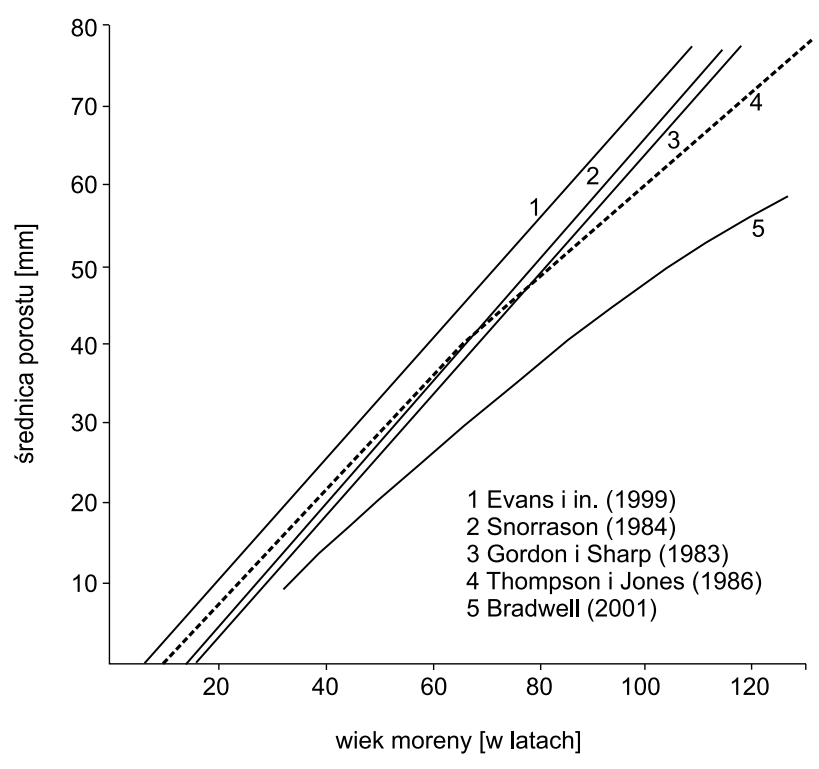

Ryc. 6. Krzywe wzrostu porostów z rodzaju Rhizocarpon na SE Islandii opracowane przez różnych badaczy

Fig. 6. Growth curves of Rhizocarpon genus lichens in SE Iceland elaborated by different authors

rozmiar największej plechy, średnią z pomiarów 5 największych plech oraz średnicę hipotetycznej (1 na 1000) plechy wyznaczonej poprzez ekstrapolację krzywej regresji. Wiek powierzchni skalnej oblicza się, stosując krzywą wzrostu otrzymaną z pomiarów plech porostów na powierzchniach o znanym wieku (np. mosty, groble, nagrobki). W niniejszych badaniach zastosowano krzywą wzrostu opracowaną przez Thompsona i Jonesa (1986) dla przedpoli lodowca Skaftafells i lodowca Svinafells, wypływających z południowej części czaszy lodowca Vatna (z drobnymi modyfikacjami). Według tej krzywej, pierwsze porosty pojawiają się po około 10 latach od zdeponowania osadu (tzw. odstęp kolonizacyjny), porosty młodsze niż 50-60 lat (w badaniach autorów przyjęto dla uproszczenia 55 lat) wzrastają z prędkością $0,725 \mathrm{~mm} \mathrm{a}^{-1}$, natomiast starsze z prędkością 0,585 $\mathrm{mm} \mathrm{a}^{-1}$. Spośród wielu różnych publikowanych krzywych wzrostu porostu Rhizocarpon na południowo-wschodniej Islandii (Gordon, Sharp 1983, Snorrason 1984, Evans i in. 1999, Bradwell 2001) krzywa Thompsona i Jonesa (1986) wydaje się pośrednia (Dąbski 2002) (ryc. 6). W celu zobrazowania możliwej zmienności warunków środowiskowych na poszczególnych wałach morenowych ich wiek obliczono przy użyciu trzech wartości odstępu kolonizacyjnego: 10,15 i 20 lat.

Otrzymane daty zostały w dalszym etapie analiz porównane $\mathrm{z}$ wynikami badań glacjologicznych dla profilu Fláajökull austur 2 (Sigurðsson 1998) oraz z wynikami datowań lichenometrycznych w południowej części przedpola lodowca Fláa (Dąbski 2002, 2007). Roczne zmiany zasięgu czoła lodowca, rejestrowane wzdłuż profilu Fláajökull austur 2 od 1934 r., zostały kolejno skumulowane, a następnie przedstawione na wykresie (ryc. 2). Okresy względnego postoju lodowca interpretowane są jako prawdopodobne etapy depozycji moren. Korelację wałów morenowych w obu częściach przedpola oparto na analizie stereoskopowej pary zdjęć lotniczych z roku 1989 oraz zdjęć satelitarnych z roku 2012.

\section{Wyniki badań}

Największe zróżnicowanie wielkości plech jest widoczne na najstarszym wale morenowym (I). Populacje porostów na młodszych wałach morenowych (II i III) są mniej zróżnicowane. Zależność tę potwierdza wzrost wartości gradientu rozkładu częstości (współczynnika kierunkowego krzywych regresji) w kierunku najmłodszego wału od 0,0549 do 0,1013 . Wskaźnik korelacji $\mathrm{R}^{2}$ jest stosunkowo niski, jego wartości nie wykazują prawidłowości (ryc. 4).

Wiek moren obliczono czterema metodami: GSF, LL, 5LL oraz 1-IN-1000 (tab. 1). Wyniki otrzymane każdą z metod różnią się od siebie. Jedynie w przypadku wału I w metodzie GSF oraz LL otrzymano ten sam wynik - 1904 r.

Najwyższa korelacja z wynikami opartymi na danych glacjologicznych (por. Dąbski 2002) występuje dla metody LL oraz opóźnienia kolonizacyjnego 20 lat w przypadku wałów I i II, natomiast 15 lat dla wału III (tab. 1). W odniesieniu do metod 5LL i 1-IN-1000 wysoką korelację ( \pm 2 lata) można zauważyć jedynie dla opóźnienia kolonizacyjnego 20 lat dla wału morenowego III, natomiast wieki wałów morenowych I i II są wyraźnie starsze.

Uzyskane wyniki badań wskazują na istniejące różnice w liczbie porostów porastających poszczególne części głazu wydzielone pod względem ekspozycji (proksymalna, dystalna, wierzchowinowa). W przypadku wałów

Tabela 1. Wiek wałów morenowych lodowca Fláa obliczony metodami: GSF, LL, 5LL oraz 1-IN-1000. Kolorem szarym zaznaczono wiek o wysokiej ( \pm 2 lata) korelacji z wynikami Dąbskiego (2002).

Table 1. The age of the Fláajökull glacier moraine ridges derived from methods: GSF, LL, 5LL and 1-IN-1000. Grey colour indicates the age showing high correlation ( \pm 2 years) with results of study by Dąbski (2002).

\begin{tabular}{|c|c|c|c|c|c|c|c|c|c|c|c|c|}
\hline \multirow{3}{*}{$\begin{array}{c}\text { Wał } \\
\text { morenowy }\end{array}$} & \multicolumn{3}{|c|}{ LL } & \multicolumn{3}{|c|}{$5 \mathrm{LL}$} & \multicolumn{3}{|c|}{$1-\mathrm{IN}-1000$} & \multirow{3}{*}{ GSF } & \multirow{3}{*}{$\begin{array}{c}\text { Datowania } \\
\text { Dąbskiego } \\
2002 *\end{array}$} & \multirow{3}{*}{$\begin{array}{c}\text { Datowania } \\
\text { Dąbskiego } \\
2007^{*}\end{array}$} \\
\hline & \multicolumn{3}{|c|}{$\begin{array}{l}\text { Wartości odstępu } \\
\text { kolonizacyjnego }\end{array}$} & \multicolumn{3}{|c|}{$\begin{array}{l}\text { Wartości odstępu } \\
\text { kolonizacyjnego }\end{array}$} & \multicolumn{3}{|c|}{$\begin{array}{l}\text { Wartości odstępu } \\
\text { kolonizacyjnego }\end{array}$} & & & \\
\hline & 10 & 15 & 20 & 10 & 15 & 20 & 10 & 15 & 20 & & & \\
\hline I & 1904 & 1899 & 1894 & 1913 & 1908 & 1903 & 1920 & 1915 & 1910 & 1904 & $1870 / 94$ & 1898 \\
\hline II & 1937 & 1932 & 1927 & 1943 & 1938 & 1933 & 1940 & 1935 & 1930 & 1948 & $1920 / 25$ & 1930 \\
\hline III & 1938 & 1933 & 1928 & 1947 & 1942 & 1937 & 1944 & 1939 & 1934 & 1954 & $1934 / 35$ & 1944 \\
\hline
\end{tabular}

* wały morenowe I, III i V w S części przedpola badane przez Dąbskiego $(2002,2007)$

* moraine ridges I, III and V in the S part of the foreland, studied by Dąbski $(2007,2002)$ 

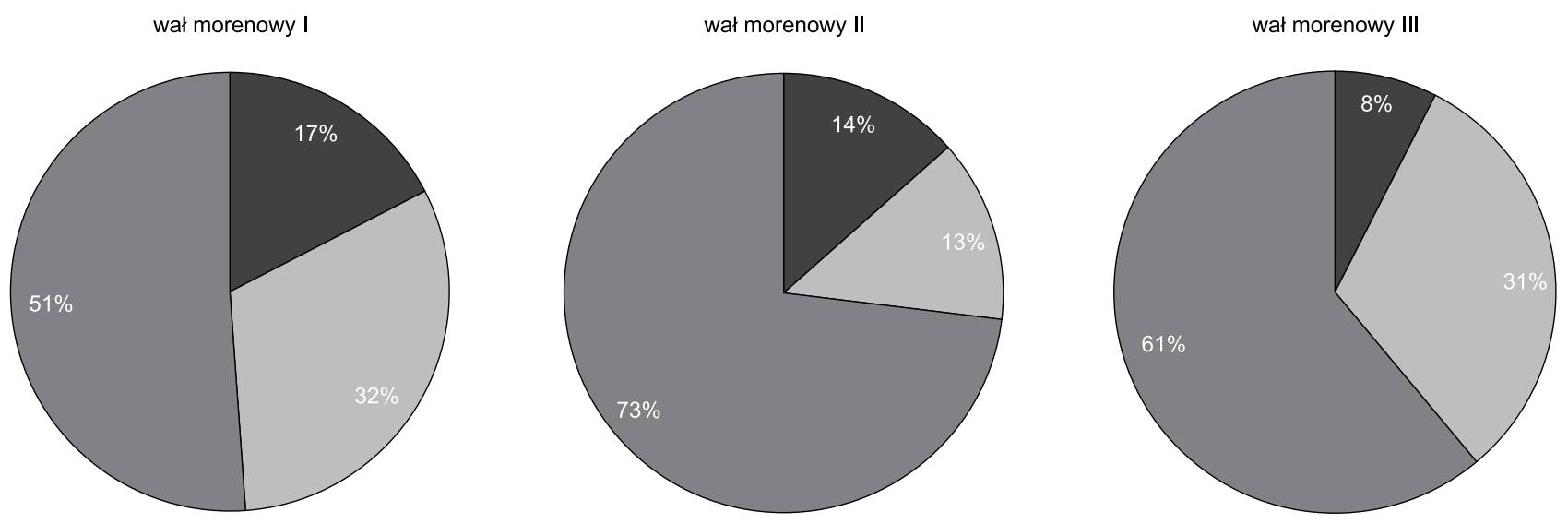

populacje porostów: $\square$ proksymalna $\square$ dystalna $\square$ wierzchowinowa

Ryc. 7. Procentowy udział części populacji proksymalnych, dystalnych i wierzchowinowych w ogólniej liczbie porostów na każdym z wałów morenowych

Fig. 7. The percentage share of proximal, distal and upper populations in overall number of lichens on each moraine ridge

morenowych I oraz III strona proksymalna jest najmniej chętnie porastana przez Rhizocarpon, natomiast na wale morenowym II wyraźną dominację wykazuje część wierzchowinowa (ryc. 7). Najprawdopodobniej jest to spowodowane faktem, że porosty wybierają ciepłe części głazów, nie nastawione bezpośrednio na działanie zimnych, katabatycznych wiatrów lodowcowych. Wyniki te są zbliżone do otrzymanych przez Dąbskiego (2007).

Rezultaty analizy rozkładu gradientu częstości plech na poszczególnych wałach morenowych z wyróżnieniem strony głazu, którą porastały, wskazują, że gradient częstości plech na stronie proksymalnej nie zmienia się w znaczący sposób (ryc. 8). Odnotowuje się natomiast znaczny wzrost gradientu częstości porostów na stronie dystalnej i wierzchowinowej na najmłodszym wale morenowym (III) oraz na stronie wierzchowinowej na wale środkowym (II). Widać zatem, że największym zróżnicowaniem rozmiarów plech w obrębie wału, czyli niskim gradientem częstości, charakteryzują się populacje proksymalne. Wzrost gradientu w kierunku wałów młodszych,

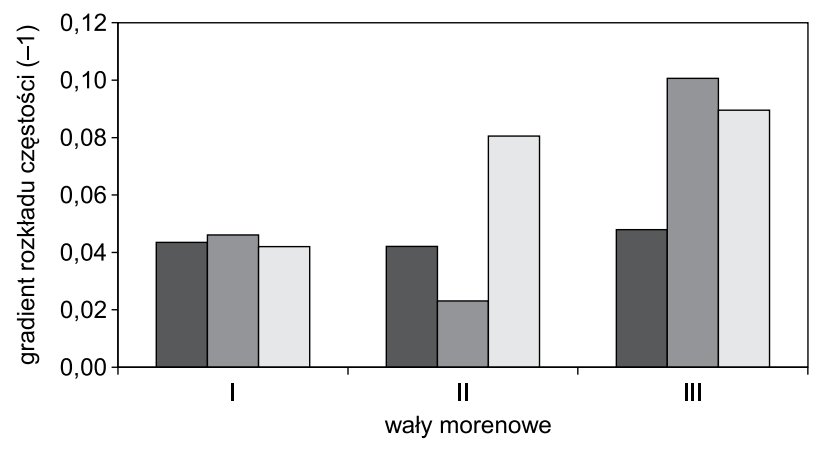

populacje porostów: $\square$ proksymalna $\square$ dystalna $\square$ wierzchowina

Ryc. 8. Gradient rozkładu częstości przemnożony przez współczynnik -1 dla populacji proksymalnych, dystalnych i wierzchowinowych na poszczególnych wałach morenowych

Fig. 8. The gradient of the size-frequency distribution multiplied by coefficient -1 for proximal, distal and upper populations on each moraine ridge odnotowany dla populacji wierzchowinowych i dystalnych, wskazuje zaś na szybki spadek wielkości plech, a tym samym wieku tych populacji, wraz $\mathrm{z}$ malejącym wiekiem wału.

\section{Dyskusja}

Dotychczasowe badania wieku akumulacji osadów wałów moren czołowych na przedpolu lodowca Fláa nie dają jednoznacznych wyników (Dąbski 2002, 2007).

Na podstawie analizy zdjęć lotniczych i obrazów satelitarnych stwierdzono, że wały morenowe o numerach I, II, III odpowiadają najprawdopodobniej wałom I, III, V położonym w południowej części przedpola lodowca Flàa (por. Dąbski 2007) (ryc. 9). Korelując te formy ze sobą, można stwierdzić, że daty otrzymane przy zastosowaniu metody GSF są wcześniejsze niż daty uzyskane tą samą metodą przez Dąbskiego (2007) - od 6 lat różnicy w przypadku wału morenowego I, do 18 lat w przypadku wału morenowego II. Różnica ta może wskazywać na różne tempo cofania się lodowca - większe w części południowej, mniejsze w części wschodniej. Różnice w czasie i szybkości recesji pomiędzy różnymi częściami lobu lodowcowego potwierdzają badania glacjologiczne (Sigurðsson 1998). W latach 1934-1972 można wyróżnić 4 główne etapy prawdopodobnej depozycji osadów wałów morenowych. We wszystkich profilach mają one miejsce w podobnym czasie. W profilu Fláajökull astur 2 (część wschodnia) formowanie wałów morenowych nastąpiło w latach 1937-1938, 1942-1945, 1948-1952 oraz 1954-60, natomiast w profilu Fláajökull Hólmsárgarður (część południowa) w latach 1937-1941, 1944-1945, 1947-1952 oraz 1955-1957 (ryc. 2). Widoczne są jednak różnice w długości względnego postoju czoła lodowca oraz liczbie i wielkości jego wahań w tym czasie. W profilu Fláajökull austur 2 ostatnie dwa etapy stagnacji lodowca, odpowiadające uzyskanym wiekom wałów morenowych II i III, są wyraźne i obejmują kilkuletni odcinek 


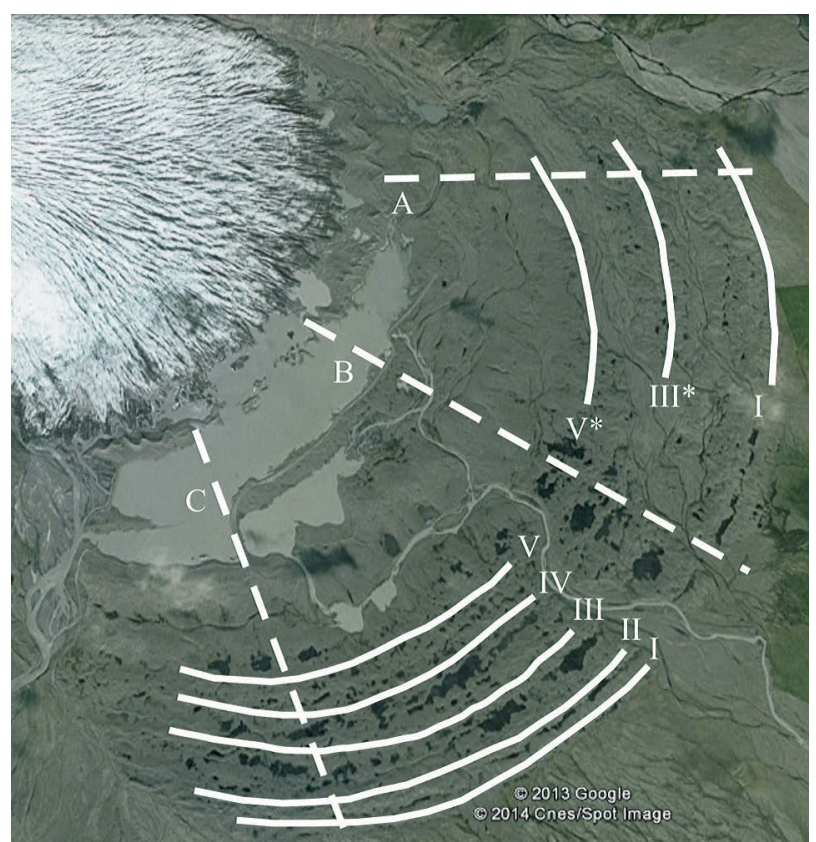

Ryc. 9. Obraz satelitarny przedpola wschodniego lobu lodowca Fláa

A - profil glacjologiczny Fláajökull austur 2, B - profil glacjologiczny Fláajökull austur 1, C - profil glacjologiczny Fláajökull Hólmsárgarður *numeracja wałów w obu częściach przedpola za Dąbskim (2007), wały III i V w części wschodniej przedpola odpowiadają wałom II i III opisywanym w tekście

Źródło: Google Earth, Cnes/Spot Image

Fig. 9. The satellite image of the foreland of the Fláajökull eastern lobe

A - glaciological profile Fláajökull austur 2, B - glaciological profile Fláajökull austur 1, C - glaciological profile Fláajökull Hólmsárgarður *numeration of ridges in both parts of the foreland after Dąbski (2007), ridges III and $\mathrm{V}$ in the eastern part of glacier forefield refer, respectively, to ridges II and III described in the text

Source: Google Earth, Cnes/Spot Image

czasu, co wskazuje na wysokie prawdopodobieństwo powstania dużych, czytelnych w rzeźbie terenu wałów morenowych. Dwa poprzednie etapy potencjalnej depozycji osadów morenowych charakteryzuje krótki czas trwania oraz liczne niewielkie oscylacje $\mathrm{w}$ ruchu lodowca, co mogło utrudniać depozycję osadów moren czołowych. Można więc przypuszczać, że we wschodniej części lobu wały moren czołowych powstałe w latach 1937-1945 nie są wyraźnie wykształcone lub nie powstały, podczas gdy w części południowej dochodziło do wyraźnej depozycji osadów wałów morenowych. Zarówno analiza zdjęć lotniczych i obrazów satelitarnych, jak i badania terenowe potwierdzają, że wałów moren czołowych w części wschodniej przedpola lodowca Fláa jest mniej oraz że są to formy mniej wyraźnie wykształcone niż w jego części południowej (ryc. 9). Tym samym można przypuszczać, że odpowiadające sobie lokalizacyjnie (na podstawie zdjęć lotniczych) wały w częściach wschodniej i południowej przedpola lodowca Fláa są różnowiekowe, a dynamika ruchu lodowca różniła się w obrębie lobu. Nie można również wykluczyć, że badane wały morenowe odpowiadają w rzeczywistości wałom młodszym niż te analizowane przez Dąbskiego (2007).
Wpływ na otrzymane różnice wyników datowania lichenometrycznego może mieć też wielkość mierzonych populacji porostów. Dąbski (2007) mierzył od 496 do 942 plech na wale, podczas gdy w prezentowanych badaniach populacje były około 2 razy mniej liczne (260-270 plech przypadających na wał morenowy). Mniejsze populacje dają wartości bardziej skumulowane $\mathrm{z}$ uwagi na zbliżony rozmiar plech i mniejsze prawdopodobieństwo trafienia na plechy największe. Znalezienie precyzyjnej granicy wyznaczającej minimalną wielkość mierzonej populacji jest niemożliwe, przede wszystkim z uwagi na indywidualne cechy każdej z powierzchni. Można jednak przypuszczać, że dolnej granicy należy szukać pomiędzy 250 a 350 pomiarów plech na wał. Przedział ten, zastosowany w badaniach autorów oraz przez Bradwella (2000, 2004), wydaje się dawać wiarygodne wyniki. Warto również mieć na uwadze zmieniającą się ogólną liczbę porostów porastających wały morenowe, bowiem na wale najstarszym będzie ich więcej niż na wale najmłodszym. Aby lepiej zobrazować rozkład klas wielkości porostów na wałach morenowych, należałoby dokonywać proporcjonalnie większej ilości pomiarów na wałach starszych. W ten sposób uzyska się na każdym z wałów zbliżony procent pomierzonych plech $\mathrm{w}$ stosunku do całkowitej populacji.

Wiek moren obliczony przy użyciu pozostałych metod wykazuje dość dobrą korelację z wynikami otrzymanymi metodą GSF - różnice są mniejsze niż 26 lat. Rozbieżności pomiędzy wynikami z poszczególnych metod otrzymane przez Dąbskiego (2007) sięgały ponad 100 lat dla najstarszych wałów. Ponadto uzyskano wysoki stopień korelacji z wynikami datowań Dąbskiego (2007), zwłaszcza dla metody LL. Jest to logiczna zależność, $\mathrm{z}$ powodu mniejszego rozmiaru pomierzonej populacji. Większe populacje na ogół charakteryzują się większą różnorodnością, co w efekcie może generować większe rozbieżności pomiędzy wynikami metody GSF a metodą LL lub 5LL.

Do błędnego datowania wieku moreny, zwłaszcza metodami LL i 5LL, może prowadzić obecność porostów o anomalnej wielkości, a także większa liczba pokoleń porostów, które mogą być skutkiem wieloetapowego osiadania i stabilizowania się wału moreny. Mniejsze populacje, a w przypadku metod LL i 5LL zwykle jest to jeden bądź kilka pomiarów, nie dają możliwości dostrzeżenia ewentualnych anomalii. Mogą być one natomiast łatwo zauważone przy analizie diagramów częstości poprzez stwierdzenie obecności rozkładu bimodalnego. Dodatkowo niejednorodną populację charakteryzuje niska wartość gradientu rozkładu częstości i wskaźnika $\mathrm{R}^{2}$. Wartości te powinny być najniższe dla populacji starszych, bardziej oddalonych od czoła lodowca, oraz najwyższe dla populacji porastających najmłodszy wał morenowy. Na niekorzystny wpływ na wyniki datowania, jaki powoduje obecność plech o ekstremalnej wielkości, wskazywali m.in. Bradwell (2004) oraz Dąbski (2007). Dąbski (2007) zaproponował w takich przypadkach odrzucenie największych plech, co prowadziło do uzyskania bardziej wiarygodnych wyników oraz uzyskania zależności spadku war- 
tości gradientu rozkładu częstości i wskaźnika $\mathrm{R}^{2} \mathrm{~W}$ miarę oddalania się od lodowca. Związek ten, w przypadku moren sąsiadujących z lodowcem Fláa, odnotowali również Bradwell (2004) oraz McKinzey i in. (2004). Na przedpolu lodowca Fláa autorzy stwierdzili jedynie istnienie związku wieku i lokalizacji moren dla gradientu rozkładu częstości. Wskaźnik $\mathrm{R}^{2}$ wykazuje zbliżone wartości.

Z uwagi na eksponencjalny kształt krzywej, na której opierają się datowania lichenometryczne, wiarygodne wyniki można uzyskać dla osadów o wieku od 50 do 250 lat (ryc. 5). Wartości gradientu poniżej 0,02 (wiek >250 lat), mimo że różnicują się nieznacznie, odpowiadają bardzo szybkiemu wzrostowi wieku moren. Z kolei datowanie najmłodszych osadów jest obarczone błędem ze względu na istnienie asymptoty w punkcie odpowiadającym wiekowi około 25 lat, która powoduje dużą tolerancję gradientu, przy jednocześnie bardzo małym różnicowaniu się wieku. Ponadto w przypadku bardzo młodych populacji mamy do czynienia z małą różnorodnością rozmiarów plech. Dlatego też należy zachować szczególną ostrożność w datowaniu młodych osadów, młodszych niż około 50 lat.

Wieki moren obliczone przy użyciu trzech różnych wartości odstępu kolonizacyjnego wskazują na zróżnicowanie czasu pojawienia się pierwszych porostów na poszczególnych wałach. Korelacja z wynikami opartymi na danych glacjologicznych (por. Dąbski 2002) wskazuje na to, że odstęp kolonizacyjny na wale morenowym III był około 5 lat krótszy niż na wałach I i II. Wartość opóźnienia kolonizacyjnego przyjmowana dla obliczeń wieku moren jest wielkością średnią, gdyż na jej rzeczywisty poziom wpływa wiele czynników indywidualnych dla każdego z wałów morenowych. Jednym z głównych czynników powodujących wydłużenie okresu opóźnienia (kolonizacyjnego) jest obecność brył martwego lodu w obrębie wału moreny, którego topnienie prowadzi do destabilizacji powierzchni wału. Skutkiem jest niemożność rozwoju kolonii porostów na tej powierzchni (Gordon, Sharp 1983, Everest, Bradwell 2003). Obecnie zaleganie brył martwego lodu w obrębie wałów moren stwierdzono dla najmłodszego wału, jednak zapisy w postaci struktur z wytopienia brył lodu były notowane m.in. przez Jakscha (1985) i Dąbskiego (2002) oraz w trakcie pomiarów terenowych związanych $\mathrm{z}$ prowadzonymi przez autorów badaniami. Innymi czynnikami powodującymi wydłużenie okresu kolonizacyjnego są m.in. fluktuacje w ruchu lodowca, zmiany klimatyczne i środowiskowe oraz procesy peryglacjalne.

Na różnicowanie się tempa wzrostu poszczególnych gatunków porostów, także w obrębie jednego rodzaju, wskazywali m.in. Innes (1982) oraz Armstrong i Bradwell (2010). Niniejsze pomiary przeprowadzono na porostach z rodzaju Rhizocarpon, bez dokonywania rozróżnień poszczególnych gatunków. Mimo że potencjalne różnice tempa wzrostu nie powinny oddziaływać znacząco na wyniki, brak w tej kwestii dokładnych danych. Jedynie w niewielkim stopniu poznany jest również wpływ warunków środowiskowych i mikrośrodowiskowych na rozwój porostów. Istnieje wiele przesłanek, że nawet niewielkie zmiany środowiskowe mogą silnie oddziaływać na tempo wzrostu plech. Haines-Young (1983) wskazał na istnienie strefy u podstawy proksymalnych stoków moren, tzw. green zone, w której wzrost plech odbywa się szybciej niż w częściach dystalnych i wierzchowinowych. Podobnie Dąbski (2007) odnotował zależność tempa wzrostu plech od ekspozycji powierzchni głazu, na której rośnie plecha. Stwierdził on stosunkowo mniejszą liczbę porostów na powierzchniach proksymalnych głazów w porównaniu do liczby porostów w częściach wierzchowinowych i dystalnych. Na podstawie zróżnicowania gradientu rozkładu częstości na poszczególnych stronach głazu wysunął również tezę, potwierdzającą badania Armstronga (2002). Według tej tezy, pierwsze porosty pojawiają się na stronach proksymalnych, po czym, z uwagi na ich większą śmiertelność oraz na szybszy wzrost plech w częściach wierzchowinowych i dystalnych, ich udział spada na korzyść porostów na cieplejszych stronach głazów. Powyższa zależność doskonale widoczna jest w przypadku wału morenowego III oraz w mniejszym stopniu na wale I (ryc. 7). Zależność ta nie występuje jednak w odniesieniu do wału II, co może być efektem stosunkowo niewielkiej populacji porostów. Populacje wydzielone na podstawie ekspozycji są znacznie mniejsze niż rozmiar populacji wszystkich porostów na wale. Porosty zajmujące stronę dystalną na wale morenowym II stanowią jedynie 13\% spośród wszystkich pomierzonych plech. Tak niewielka populacja może nie ukazywać w pełni zmienności rozmiarów plech. Ponadto w przypadku analizowanej wschodniej części przedpola lodowca Fláa, strona dystalna ma ekspozycję wschodnią, a więc charakteryzuje się nieco mniej korzystnym mikroklimatem niż ekspozycja południowa w badaniach Dąbskiego (2007), co również może wpływać na wyniki datowania. Dodatkowo powyższy schemat potwierdza częstość występowania poszczególnych klas wielkości plech w zależności od kierunku ekspozycji, z wyraźnie najmniejszym udziałem plech na stronach proksymalnych (ryc. 8). Mało prawdopodobne jest więc, aby kolejność kolonizacji zaobserwowana w przypadku pozostałych wałów morenowych oraz w badaniach Dąbskiego była inna dla wału morenowego II. Dokładne rozpoznanie wpływu warunków mikrośrodowiskowych na wzrost porostów wymaga więc dalszych badań.

\section{Wnioski}

Przeprowadzone badania uzupełniają dotychczasowy zbiór danych na temat tworzenia się form morenowych przedpola wschodniego lobu lodowca Fláa. Ponadto wyniki analiz umożliwiają porównanie tradycyjnych metod lichenometrycznych z datowaniem opartym na gradiencie rozkładu częstości i krzywej Bradwella (2004). Główne wnioski są następujące:

1. Do zalet lichenometrii należy względna prostota wykonania badań oraz niskie koszty i wymagania sprzę- 
towe. Datowanie lichenometryczne, choć obarczone pewnymi błędami i zależne od liczebności próby, daje dokładność pozwalającą na datowanie młodych (50250 lat) form polodowcowych.

2. Uzyskane wyniki datowania wskazują, że maksymalny zasięg lodowca Fláa przypada na przełom XIX/ XX w., co pozostaje w zgodności z wynikami poprzednich badań, wskazujących na rozpoczęcie się recesji czoła tego lodowca wraz z końcem małej epoki lodowej (koniec XIX w.).

3. Wiek depozycji osadów wałów moren czołowych lodowca Fláa we wschodniej części jego przedpola jest młodszy niż wynika to z datowań Dąbskiego (2002, 2007) dla form morenowych w południowej części przedpola tego lodowca. Niezgodności nie osiągają jednak dużych wartości, a czas depozycji osadów morenowych wykazuje korelację z wynikami badań glacjologicznych (Sigurðsson 1998). Można więc przypuszczać, że wały morenowe tworzyły się w odmiennym czasie $\mathrm{w}$ różnych częściach przedpola lodowca Fláa.

4. Rozbieżność pomiędzy latami depozycji osadów wałów morenowych, uzyskanymi za pomocą metody GSF dla populacji o różnej wielkości, może wskazywać również na zależność wyników datowania od liczebności pomierzonej populacji plech. Przedział 250-350 pomiarów plech przypadający na jeden wał morenowy wydaje się wystarczający do uzyskania wiarygodnych wyników datowania. Jednocześnie należy mieć na uwadze zależność wielkości populacji od wieku wału.

5. Na wyniki datowania lichenometrycznego mają wpływ warunki mikrośrodowiskowe. Obecność brył martwego lodu może opóźniać czas wkroczenia pierwszych porostów na wał morenowy, przez co stosowanie stałej wartości odstępu kolonizacyjnego dla wszystkich wałów może powodować błędy.

6. Liczebność porostów oraz tempo wzrostu plech zależą od ekspozycji analizowanej powierzchni. Efekt ten jest widoczny zarówno w wynikach datowania uzyskanych przez autorów, jak i w opracowaniach wcześniejszych (Dąbski 2007). Wpływ zróżnicowania mikroklimatycznego na te wyniki nie jest jednak w pełni poznany i wymaga przeprowadzenia dalszych analiz.

\section{Podziękowania}

Badania zostały zrealizowane dzięki dotacjom z funduszy Rady Konsultacyjnej ds. Studenckiego Ruchu Naukowego Uniwersytetu Warszawskiego oraz Fundacji Uniwersytetu Warszawskiego, za co autorzy serdecznie dziękują. Autorzy dziękują też anonimowemu recenzentowi za wnikliwe udoskonalenie pierwotnej wersji manuskryptu.

\section{Literatura}

Armstrong R.A., 2002. The effect of rock surface aspect on growth, size structure and competition in the lichen Rhizocarpon geographicum. Environmental and Experimental Botany 48: 187-194.

Barnett D.M., 1967. Development landforms and chronology of Generator Lake, Baffin Island, North West Territories. Geographical Bulletin 9: $169-88$.

Armstrong R.A., Bradwell T., 2010. Growth lichens: a review. Geografiska Annaler 92A(1): 3-17.

Benedict J.B., 1967. Recent glacial history of an alpine area in the Colorado Front Range, USA. I. Establishing a lichen growth curve. Journal of Glaciology 6: 817-832.

Benedict J.B., 1985. Arapaho Pass: glacial geology and archeology at the crest of the Colorado Front Range. Center for Mountain Archeology, Research Report 3.

Beschel R., 1950. Flechten als Altersmasstab rezenter Moranen. Zeitschrift fur Gletcherkunde und Glazialgeologie 1: 152-161.

Bradwell T,. 2001. A new lichenometric dating curve for southeast Iceland. Geografiska Annaler 83A: 91-101, DOI: 10.1111/j.0435$-3676.2001 .00146 . x$.

Bradwell T., 2004. Lichenometric dating in southeast Iceland: the size-frequency approach. Geografiska Annaler 86A: 31-41, DOI: 10.1111/j.0435-3676.2004.00211.x.

Bradwell T., 2009. Lichenometric dating: a commentary, in the light of some recent statistical studies. Geografiska Annaler 91A(2): 61-69.

Bradwell T., Dugmore J.A., Sugden D.E., 2006. The Little Ice Age glacier maximum in Iceland and the North Atlantic Oscillation: evidence from Lambatungnajökull, southeast Iceland. Boreas 35: 61-80, DOI:10.1080/03009480500359202.

Chenet M., Roussel E., Jomelli V., Grancher D., 2010. Asynchronous Little Ice Age glacial maximum extent in southeast Iceland. Geomorphology 114: 253-260.

Cooley D., Naveau P., Jomelli V., Rabatel A., Grancher D., 2006. A Bayesian hierarchical extreme value model for lichenometry. Environmetrics 17: 555-574.

Dąbski M., 2002. Dating of the Fláajökull moraine ridges, SE - Iceland; comparison of the glaciological, cartographic and lichenometrical data. Jökull 51: 17-24.

Dąbski M., 2005. Zastosowanie lichenometrii w badaniach geomorfologicznych. Monitoring Środowiska Przyrodniczego 6: 41-45.

Dąbski M., 2007. Lichenometryczna analiza rozkładu częstości jako metoda datowania moren lodowca Fláa (SE Islandia). Słupskie Prace Geograficzne 4: 61-77.

Dąbski M., 2012. Determining rock surface micro-roughness and search for new method of relative dating of glacial landforms; a case study from Fláajökull (SE Iceland) and Biferten glacier (Swiss Alps) forefields. Landform Analysis 21: 3-8.

Dąbski M., Fabiszewski, Pękalska A., 1998. Marginal zone of Fláajökull (Iceland). Initial result of research. Miscellanea Geographica 8: 47-54.

Evans D.J.A., Archer S., Wilson D.J.H., 1999. A comparison of the lichenometric and Schmidt hammer dating techniques based on data from the proglacial areas of some Icelandic glaciers. Quaternary Science Reviews 18: 13-41.

Everest J., Bradwell T., 2003. Buried glacier ice in southern Iceland and its wider significance. Geomorphology 52: 347-358.

Gordon J.E., Sharp M., 1983. Lichenometry in dating recent glacial landforms and deposits, southern Iceland. Boreas 12: 191-200.

Haines-Young R.H., 1983. Size variation of Rhizocarpon on Moraine Slopes in Southern Norway. Arctic and Alpine Research 15: 295-305.

Innes. J.L., 1982. Lichenometric use of an aggregated Rhizocarpon 'species'. Boreas 11: 53-57.

Innes J.L., 1985. Lichenometry. Progress in Physical Geography 9: 187-254.

Jaksch K., 1975. Das Gletschervorfeld des Solheimajökull. Jökull 25: 34-38.

Kirkbridge M.P., Dugmore A.J., 2001. Can lichenometry be used to date the "Little Ice Age" glacial maximum in Iceland? Climatic Change 48: 151-167.

Lock W.W., Andrews J.T., Webber P.J., 1979. A manual for lichenometry. British Geomorphological Research Group, Technical Bulletin 26. 
Mckinzey K.M., Orwin J.F., Bradwell T., 2004. Re-dating the moraines at Skalafellsjökull and Heinabergsjökull using different lichenometric methods: implications for the timing of the Icelandic Little Ice Age maximum. Geografiska Annaler 86A: 319-335, DOI: 10.1111/j.0435$-3676.2004 .00235 . x$.

Naveau P., Jomelli V., Cooley D., Rabatel A., 2007. Modeling uncertainties in lichenometry studies with an application: the Tropical Andes (Charquini Glacier in Bolivia). Arctic, Antarctic, and Alpine Research 39: $277-285$
Naveau P., Nogaja M., Ammann C., Yiou P., Cooley D., Jomelli V., 2005. Statistical methods for the analysis of Geophysical extreme events. Comptes Rendus de l'Académie des Sciences 337: 1013-1022.

Sigurðsson O., 1998. Glacier variations in Iceland 1930-1995 from database of the Iceland Glaciological Society. Jökull 45: 3-25.

Snorrason S., 1984. Myrarjoklar og Vatnsdalur. MS, Oslo University. Thompson A., Jones A., 1986. Rates and causes of proglacial river terrace formation in southeast Iceland: an application of lichenometric dating techniques. Boreas 15: 231-246, DOI: 10.1111/j.15023885.1986.tb00928.x. 